\title{
Managing the Public Service Institution
}

Important factors involved in the management of public service institutions, of which the library is one example, are discussed. Included are the requirement to know the publics and their expectations and service needs; the problems related to the introduction of new programs; the roles of the administrator and the professional; the mission of the institution; and the need to communicate effectively to society the institution's unique contribution in order to merit and to receive continuing support.

$\mathbf{M}_{\mathrm{r}}$ but managing the service institution. I deliberately put it this way because, in the first place, I know nothing about running a library. I am old enough to remember when a library was a place where you kept books and made sure that those enemies of books, human beings, didn't come close to them. However, I know the situation has changed fundamentally since then, and that is the other reason I chose that title. I wanted to emphasize the fact that from a place where you kept books lovingly and with great concern for their safety and preservation, the library has become a place that serves a multitude of users-a place where the emphasis has shifted from book worship to the providing of information services. Let me start out by noting that most of the problems one will face cannot be solved. They can only be survived. But at least one can attempt to understand them.

When I look at service institutions

Peter F. Drucker is Clarke Professor of the Social Sciences, Claremont Graduate School, Claremont, California. This article is based upon an address delivered at a meeting of the Association of College and Research Libraries on June 30, 1975, in San Francisco during the ALA Annual Conference. such as libraries, and I have done a good deal of this, I am always struck by how few are the things one has to keep in mind in order for them to carry out their functions with the greatest possible satisfaction for the people who use them and work in them. There are only a few basic essentials. Unfortunately, they are very rarely given proper attention, simply because the daily work is so demanding and pregnant with crises of all sorts. Librarians are operating people, and that means that at five minutes past 9:00 a.m. the daily crisis arrives on your desk. If it doesn't, you'll go out and start one.

Most of my friends are trained arsonists, and librarians have the same sound instincts. In the first place, the crisis is something they know how to deal with. Secondly, they sometimes react like the Irish mother of seventeen children who, as long as there is hell upstairs, goes quietly and happily about her daily chores, but when it's quiet upstairs, goes to the foot of the stairs and hollers, "Whatever you're doing up there, stop it." In other words, she creates a crisis where one might not exist. When things seem to be running smoothly, that is, when there is no crisis, it is dangerous because the fundamentals are always pushed into the background by the multitude of daily tasks which have to be 
accomplished. Consequently, I'm going to concentrate on those few things that constitute the foundations for those daily tasks, the first and most patently obvious of which is the importance of knowing who your publics are. If you say you already know this, then I'm going to become nasty and snarl in reply, "Then why don't you act as if you do?"

\section{The Publics}

Every service institution, and libraries are probably very typical, has a fair number of different publics. Each of these publics not only makes different demands on it, but each looks at the institution and sees something entirely different. As a matter of fact, the one thing that can be said with absolute certainty about service institutions is that their publics do not have the same image of them as do the people who toil within them. If you don't have some basic understanding of and sympathy for the expectations and frustrations of your major publics, it's highly unlikely that the library will be able to function with a high degree of effectiveness.

One of the few well-proven, truly proven, laws of psychology, and a very old one, is that what is obvious to me nobody else can see at all. You know, I have no idea what's in back of me. True, I can turn around and see what is there, but I don't know. You see very clearly, I don't. On the other hand, I see what's in back of that open door at the rear of the room, and none of you can. So what is obvious is also what is directly in the field of vision, and perhaps nobody else can see it at all. Therefore, you start out with a very clear concept of what the library is, and the only thing you can say about it is that none of your publics can possibly share that vision. It's an inside vision. It's a trained one. It's a professional one. The library to you is an end, but to your publics it is a tool. Who are your publics? Find out what they see and what they expect, and I can tell you that you are going to be surprised. $\mathrm{Oh}$, to be sure, you've probably got a number of faculty committees dealing with the library. But by now everyone of you knows the truth of the old Roman law that a slave who has three masters is a free man. You have faculty committees, and most of you worry about keeping them busy without ever letting them do any work. That is the first thing one has to learn in academic administration. And since academicians like to be busy, but don't like to do any work, it's easy.

How do you define a public? Let me say there are two definitions, and both are important. One is any group that can in effect stymie you, that can block you, that has a veto power. That's a very important definition and one which school administrators are rarely aware of. If they were, they would realize that the taxpayers are a public. The taxpayers can and do stymie the school superintendent unless he or she understands what they see when they look at the school system. And the taxpayer qua taxpayer sees the school very differently than when he or she looks at it as a parent, as a teacher, or as a member of the school board. They're all taxpayers; but the taxpayer's is a distinct point of view, and it's different from any of the others.

Who are your audiences in the sense of constituencies? People who can effectively impair you, block you, and veto you. And, secondly, who are the people who depend on you, who look to you for an input into their work? They may be students, they may be faculties, or people off campus. One has to find out what each of these publics sees when it looks at the library. They see the same building, but that's the only thing they see the same way. What is really of value to them is another matter, and you don't discover that by being intelligent, but by going out and asking. 
There are two areas in which being intelligent isn't enough. One is personnel decisions, the other is marketing. Finding out what a given public wants or expects from a library is basically a marketing decision. Who is the market, and what do they really want? It requires effort, not just intelligence and intuition, to find out.

Let me say that the world is full of businessmen who complain that their customers do not want to pay for quality. One has to say to them, "Look, my friends, the engineers and the manufacturer do not determine quality. The user does." What most manufacturers mean when they say quality is an engineering matter is that it can be achieved only at a very high price. That isn't quality, that's incompetence.

What is quality is determined by the user. What does he or she really want? What is it that you supply? You supply information. That's a very slippery term and a very broad one. For instance, some of the information supplied by libraries is related to making known the information content of the collections. The collections in and of themselves are not information. They are repositories of data. But, over and above this kind of descriptive information, libraries supply information-focused minds-people who can help that graduate student satisfy his or her need for information about trade in Iceland in the ninth century without themselves being very knowledgeable about it.

The librarian, however, knows what that youngster is really groping for and hears it. The process is very hard to define, but all of you have done it. All of you know what I'm talking about. That's also information. We don't know how one learns to do this, and we don't know how to teach it, but a good librarian has this ability. It's more than you'll find in the books. Unfortunately for most of your users, the pleasures of your library are very hard to come by, because very few of them realize that the librarian is actually a catalyst who converts data into information. Most of what you have on your shelves is data. Without this kind of human input, much of it will never come to the attention of the library's individual and collective publics. So, find out who these publics are and probe for their information needs. Discover the image of the library as they see it and work toward making them happy and satisfied-rather than keeping librarians comfortable. Discover your publics' needs, and you will have defined your service objectives.

\section{Service Objectives}

Now, you have to do certain things to render service. One of the most important elements is to provide an efficient and effective physical arrangement of human and material resources, and in my experience most librarians have been deficient here. In other words, you have to make things easily accessible. Let me give you an example of why I think librarians are deficient in this area.

I am very dependent upon a library that is part of a very good institution and that is a depository for U.S. government documents. When you come in, you have to wade through two floors that are stacked with Patent Office applications in order to use the rest of the collection. As it happens, this is very convenient for my wife as she is a patent agent. But it seems a little peculiar to arrange a big library serving 8,000 students and several hundred faculty members for the convenience of one faculty wife. But, in effect, that is the case because of an irrational physical arrangement of the collection.

Where do things belong? For that you have to know your publics, and let me say that they change more often than you think. One of the troubles with the typical library is that once librarians 
have decided where to put things, they seldom, if ever, look at the problem again. Unfortunately, your publics are aware of something that my father's generation did not know. A library is not a place where you keep books, but an institution for circulating them. It is also true that in most academic libraries, people circulate within them. Consequently, the arrangement of the library should be determined by the pattern of use, which has a way of changing over the years. Librarians need to be aware of these changes and react to them. It is a terrible job carting things around, but libraries should be rearranged so that people don't fall over each other trying to use them, so that people can find what they're looking for quickly and easily. A really functional library is one where people can better circulate, find what they want, and get out again with a minimum amount of exercise and irritation. Remember that the secret of any store is not to get people in, but to get them out again, satisfied. Look at the flow pattern and the physical arrangement of the library in terms of the changing needs of those who use it. I am sure that I have not said anything you haven't heard before. I'm simply saying, "Why don't you act on the principle you know?"

Of equal importance to knowing the needs of your publics is knowing which services in the library have become obsolete. In other words, what can be abandoned in order to reallocate resources to something that isn't getting done? This is a very difficult matter in public service institutions of all kinds, but especially so in universities. As you know, every university follows a very simple rule: if a subject becomes totally obsolete, make a required course out of it. This is a normal human reaction.

You put twenty years of your life into building something, and the tendency is to put all of your resources into defend- ing it in spite of the fact that it has become obsolete. Understandable though they may be, unless these emotional attachments are overcome, I can guarantee that your really effective resources, both human and money, will be invested in the defense of yesterday.

There is nothing that is more expensive in modern medicine than the dubious attempt to keep someone who is already dead from putrifying for a few more days or weeks. The terminal cancer patient, or someone turned into a vegetable by a series of strokes, requires around-the-clock service by a team of six nurses and five engineers and twenty pathologists. And what do you achieve? There are no results. The worse the case, the more energy is required to keep it from beginning to putrify, and yet eventually it will.

What I have been leading up to is the need for placing the few really performing people you have on the staff. Nobody has a great many. I'm talking of performance, not potential, and believe me, there's very little correlation between the two. Potential very often is only skin deep. On the other hand, a great many performers are very unspectacular. They do a good job because they aren't bright enough to do a bad one. They have no ideas or imagination, but they do a good job. And this is good, as many library jobs are very similar to putting on a fender on an automobile assembly line. Would you really want somebody with initiative and imagination in these jobs any more than you would want bank tellers with initiative and imagination if you were a bank president?

Identify your few performers, and study how they are being used. You will find, as everyone who has performed this exercise has found, that the best of your human resources are misallocated. They are not allocated to service, but to defense. In this connection, let me say the only point of a rear guard action is 
to enable the main body of the army to get away. Otherwise, one doesn't fight rear guard actions. Rear guard actions cannot gain anything except a little time. Effective resource allocation inherently involves the phasing out and phasing down of problems. Once every few years one has to ask of every activity in every service program, "If we were not doing it today, and knowing what we know now, would we do it?" If the answer is "No," then one doesn't ask, "Should we drop it?" One says, "How fast can we get out?"

\section{New Programs}

The great weakness of service organizations is the tendency toward middleage spread. They put on fat, and it's awfully hard to get rid of fat. Consequently, the next principle which you probably will honor only by not acting on it is that in service work one doesn't start anything new unless one phases out something old. The reason is a very simple one. Everything new you go into in the information field sounds awfully easy. The IBM salesman told you so, but now that you have been involved with computers for a few years you know it isn't. In fact, so far we have only paid for the computers. We have yet to see the results.

Let me say that I have no problems with computers. They work for me, but then I've always considered them large adding machines. That's all they are, and expensive ones as far as I'm concerned. So far, as you know, IBM and the other manufacturers have only sold you computers. They haven't delivered one yet, only do-it-yourself kits.

Utilizing the computer in libraries and moving into the area of nonprint media are actually very difficult operations, as most of you know, if only because we are so accustomed to the printed word. We are familiar with its potential and problems and have had long experience dealing with both. We haven't really come to terms with these newer fields as yet. Consequently, we cannot predict all of their difficulties and pitfalls. The one absolutely predictable thing, however, is that there will be troubles and there will be problems. Nothing new has ever been done without running into the most unexpected and most inane crises. It's things that just shouldn't happen, but they do. If it's an old thing, you have done it. You look at the problem. You understand it. If it's a new one, you don't. You haven't been there.

Because of this, there is a high premium on the performer. You can't help him or her very much. You can listen. You can make suggestions, but you haven't had any experience with that particular project, crisis, or problem. You need someone who has been through a few troubles and doesn't panic, someone who knows that no new system works the first time around and knows that the basic rule of new systems is that everything degenerates into work. Where are you going to get such a person? Not from the outside, because you can't afford to take that risk. You hire people from the outside for work you understand so that you can help them when they get into trouble. No, you seek for such a person inside the organization, and once identified you have to free him or her to take on new responsibilities. That means you have to be willing to slough off or downgrade or deemphasize something else. What are the things that you are doing exceedingly well that don't need doing at all? What are the things that forty years ago served a real purpose but whose contribution to the needs of users today is marginal? What are the things that sounded so good three years ago, but three years later we still don't know how to do? It isn't true that if you can define a problem you can solve it. If you cannot define it, you cannot solve it. But there are lots of problems you can define and cannot solve. We usually find this out three years too late. We find we 
lack the knowledge, or we lack resources. Or we discover that what sounded so good three years ago is now out of step with user needs. For example, most of you are still geared to the concept of liberal education.

Learn today to think at least of a university which is primarily professionally focused, simply because that's going to be the American university of the 1980s. That's where the students are, and, incidentally, the students are very largely right. It may be a very different professional education which relates a profession to our intellectual traditions and heritage, which God knows is badly needed in professional education, but it's professional education which is drawing the students. You should look ahead to the needs of the professionally oriented student with respect to the crucial problem of resource allocation. Liberal education today, unfortunately, is really a kind of smorgasbord from which the student picks a course in French, another in mathematics, another in American political history, and another in the nineteenth-century novel. $\mathrm{He}$ or she is then supposed to integrate the whole mess into an education. No one else, least of all the faculty, is prepared to do it. That may be asking a little bit more than nineteen-year-olds can be expected to accomplish. They need help, but if it is to be forthcoming, colleges and universities are going to have to reorder their priorities, and so are college and university libraries. The question that must be asked is, "What are the few things that will really make a difference if we invest in them heavily?"

Just let me say it's a question only the administration can ask. The staff, the faculty, and the students can and should help in the process of identifying the obsolete and the potentially productive programs. But the administration must make the final decisions because they require both an understanding of the library's publics and a realistic, hard- boiled assessment of resources in relation to priorities. Nobody can be a leader in everything, and any library that tries (and I know a few that have) is not going to be a good one.

\section{The Administrator AND tHE Professional}

The administrator is paid to make the risk-taking decisions; and we are badly in need of people who are both willing and able to make them, especially at a time when all of education is attempting to adjust to the needs and realities of a rapidly emerging postindustrial society. About six months ago I spoke in San Francisco to a state teachers' convention where a principal of a high school delivered an impassioned speech to the effect that it is the duty of the state government to put more children into the classroom. I made a major tactical mistake when I ventured the opinion that I didn't think governors by themselves could really make up the entire deficit in the birthrate.

We face declining enrollments. Most importantly, we face shifting enrollments. In many ways we face people who, in terms of formal education, are far better prepared than previous generations. Don't let anybody tell you differently. It isn't true that they were better prepared fifty years ago. Moreover, demography and other factors have created a situation in which young adults will have to move into fairly responsible positions much faster than previously. Young people without any demographic knowledge sense this, and they are impatient. This means that their expectations with respect to what they will get out of those four or six or eight or ten years they sit on their backsides in our establishments are changing. Consequently, it is essential to think through what needs downgrading and where the resources thus released will be invested. This is the prime responsibility of the administrator, who, I would also hope, 
occasionally spends some time as a working librarian. In professional work, one should not become purely an administrator, because, basically, one is entitled also to some human satisfaction.

Many years ago I was asked by the school of nursing of a major eastern university to make a study of career motivations of nurses, and I told them not to invest in it. I told them that every study of career motivations has shown that people go into a career for any number of reasons. There's no one reason, and the idea that one can gear admissions policies or recruitment policies to a certain motivation is a fallacy. But they insisted on it, and, indeed, I found what I expected to find. Some go into nursing because they want to help patients; others because they really want to be doctors but have neither the money nor the time; others for the perfectly sound and sane reason that it's still the easiest way to find a man; and others because it's one of the few careers open to a woman where one can drop out to raise a family and then return. That's also a very sound reason. I didn't find a single individual who went to nursing school to become a clerk.

One goes into a profession because one enjoys the work; and if you don't, don't stay in it. You will just be an unhappy person. Therefore, the idea that the administrator in professional work should be exclusively an administrator is not a good idea. There won't be much time to enjoy the "firing line," but once in a while you should get out there because that's really what you joined the profession for. Besides, it's a good idea to show the troops that you are still as good as any of them. This is a very serious point. Administrators in a profession nowadays are and must be two-headed monsters, and there is no way you can lop off one head.

If you look at the traditional approach to administration exemplified by the Ford Motor Company of 1920, you find that 99 percent of the people did es- sentially routine work with a minimum of knowledge, and a few people ran the shop. Today's typical organization is one which has a professional employee group, which means people who are more interested, and should be, in their profession than in the institution-people who look upon the institution very largely as a place that enables them to practice a profession. You don't have to be quite as extreme in this as the famous absentminded professor of medieval history who after twenty years discovered that he was no longer teaching at the University of Minnesota but at Harvard; but you do have people who want to contribute to the mission of the library at a level that does not mock the word professional.

Bluntly speaking, it has been my observation that many individuals in the professions are overtrained for the responsibilities assigned to them. This is partly due to the bureaucratic nature of the public service institutions they serve in, but it also may be related to an exaggerated notion of the training needed to enter a profession. Maybe, like all the other American professions, librarianship has overdone the formal qualifications for membership.

I still remember the day when it was suggested, very timidly, that maybe five years of formal schooling were not necessary to be a registered nurse (that must have been in 1950), but the Association of Nursing Educators decided on seven years. Today, the two-year certificate programs of the community colleges produce better nurses than the five-year program ever did, largely because they get the young women into a ward faster. Nursing is 90 percent what you do at the bedside. The same principle holds true for librarians. So maybe we overdo it. I know you're all busily plotting to make the study longer and to invent new degrees; but mind you, you will not succeed. I decided around 1960 that the educational revolution was over, and I 
probably had beaten the drum for it more than anybody else. I took a look at the projections and trends and came to the conclusion that if we kept on going the way we were, by 1995 or so nobody would be admitted to first grade without the Ph.D.

All schoolmasters fail to realize that we have achieved our objectives. The first piece of nonreligious literature is a Sumerian text called "The Plaint of a Schoolboy." It's actually the "Plaint of the Schoolmaster," and you could put it today in any school in the country and nobody would notice the difference. Ever since then every schoolmaster has tried to get a few more youngsters into school and to keep the able ones a little longer. We have reached that objective. The next goal, then, is to make sure they get more out of education. The present yield is low. Let's work on increasing the yield in a shorter span of time.

\section{The Institutional Mission}

I noted previously that professional people tend to be more interested in their profession than the institutions in which they practice it. The purpose of a hospital, however, is not to practice medicine, but to help patients. Consequently, one of the most difficult management problems in service institutions is how to imbue a staff with a sense of mission that overarches individual professional goals-to integrate them into an institution in which their professional goals are secondary. To continue the original metaphor, what matters is not whether it's good medicine that's practiced in the hospital, but whether the patient recovers. Sure, good medicine helps and poor medicine can do real damage, but, I repeat, you don't have a hospital in order to practice medicine in it.

You have the problem of integrating individuals and the institution and of establishing a sense of mission. What can you do about it? First of all, let me say that you cannot totally resolve it. The best that can be achieved is a constructive tension, but you can make it constructive in only one way, and it generally doesn't appeal to most administrators in public-service bureaucracies. It's partly work, but it's also risky. You can do it only by accepting the fact that a professional staff is a partnership or it doesn't function. Because you are affiliated with a university, which is one of the most status-conscious of institutions we know (believe me, nothing in a Catholic archdiocese is as status-conscious), establishing this concept won't be easy. However, it can be done. The first step is to sit down with all members of the professional staff and tell them to think through what the library should hold them accountable for by way of contribution and results over the next eighteen months. You can say this politely, or you can simply say, "It's your job to think through why you should be kept on the payroll." Either way, the employees are forced to think through their contribution to the institutional mission.

Let me say you will be surprised how difficult this is for people, and not because they are stupid, but because they're effort focused and work focused. I've been asking that question ever since I became a consultant, and an instant consultant at that. In April 1942 a colonel called me in and said, "Look, as of tomorrow you are the senior management consultant for production in the ordnance district." I had been a journalist, an investment banker, a teacher. How little I knew about production management and consulting you cannot imagine, because one cannot imagine an absolute vacuum. So, I said to the colonel, "What is a management consultant?" and he said, "Young man, don't be impertinent." And if you know colonels, that meant; "I don't know myself."

I learned one thing, and that was to 
ask people why they are on the payroll. Very rarely does one get a real answer. One gets the reply. "I've got 5,000 accountants working for me." Well, that's a degenerative and irreversible disease. Or one gets the answer, "I do quality control." Why? Or one very often gets the answer, "I'm always here at 9:00, and I don't go home before 5:00." When people can talk about their work, their effort, they're not idle, but they really haven't thought about why they do it at all. They are simply doing what they are doing. Once in a great while you get somebody who says, "You know, it's my job to think through the decisions our top management will have to make within the next year or two, and to make sure they get the information to make them." Or somebody who says, "It's my job to think through what our customers pay us for when they buy our product and make sure they get it." That's quality control. Very rarely do you get people who think in terms of results and contributions, simply because the daily job is so consuming, so demanding, the daily crises so predictable. But it's your job to force them to. And don't be surprised if the first time you ask that question you get a dumb stare and then a list of all the things done last week.

Educate your people to think in terms of their contributions. That is the only way one can make the professional staff do professional work of quality which both satisfies them and makes them productive. It is also the only way you have to assuage what is your biggest problem; namely, that the library is a place where an incredible amount of donkey work goes on, and there's no getting away from it. Everybody thinks a library is a place where deep thoughts float around. What floats around is mostly dust.

A library is above all a continuous attempt to impose a little order on chaos. Information is basically chaotic, and in order to make it usable you have to have some order, and that requires a great deal of donkey work. In addition, all users leave disorder in their wake because they are not concerned with costs but only with their own needs; and it takes donkey work to keep things in order.

No matter what you do, your users, whether they are your best faculty or students, leave chaos in their wake, and you run after them the way the fellow in the circus runs after the elephant with the dustpan. A lot of library work consists of dustpan carrying, and there is nothing you can do about it. It is important, however, that people realize that dustpan carrying is an important contribution, and that their work is focused on results. When donkey work loses its relationship to results, it becomes drudgery. When this happens, the institutional mission suffers.

Every good pianist practices scales five hours daily. I don't think any of us in this room would have that much patience. I know I don't, or else I might have become a musician. For there is a relation between the scales and the quality of the recital the pianist gives. A lot of librarians practice scales. You have to do it, but you also have to see the relationship to the symphony, and hear it. That is your job. It requires continuous, systematic effort with respect to forcing people to ask the question and answer it: "What should I be held accountable for?" It is during the resulting dialogue that the library's program priorities, as you see them, are communicated. You have the responsibility for the institutional mission not because of your title, but because you have the vision to see the whole and the responsibility to inspire others to see it. It's the responsibility of the professional manager to understand and exploit the leadership role. If you cannot do this, you cannot manage a professional force. Leadership isn't going to solve unionization problems. It isn't going to solve budget problems. But without it they become insoluble. 


\section{The Budget and Its Justification}

Let me say one final thing. I intentionally didn't talk about budget, and I'm not going to. But I am going to talk about what the budget problem is. The library is something very different from what it was fifty years ago. It has become an information center. Information is expensive. The problem with information is that like any high-cost resource it requires a trained user. We haven't achieved this yet on any large scale, so the cost of information centers in terms of staffing at the present time is high. On the other hand, compare those costs to alternative costs, the costs of doing it any other way. You will then see that it is relatively cheap, but still expensive in terms of dollars. It's not only expensive, but most of the outside world sees the library as a place where books are kept in and people are kept out. They do not see the library, as I hope you see it, as an information center. It will be fifty to seventy years before there is any fundamental change in this attitude. Most physicians I know see yesterday's hospital, which was a place where the poor went to die. They don't see today's hospital. They don't understand. That, too, is one of your problems.

You have to think through what are meaningful results for your users. You know how to measure, maybe. You know a few things, the number of volumes you have, how many people come in and out, and how many volumes are circulated. Whether these statistics reflect the level of user satisfaction is very doubtful. There are things we can count, but that doesn't make them appropriate measurements of results.

Your basic financial problem is that you start out with the assumption and the assertion that books are the main business of the library, the absolute good. To the rest of us they are a relative one. Yet, you continue to hold to your position for the simple reason that it is very hard for a professional group to realize that in the end the needs of the consumer will prevail.

Now then, as long as things are booming and budgets go up, all books are good, everybody likes them, especially the nice exhibitions of early-nineteenthcentury pornographic books which are so appealing to students. Books are also appealing to accrediting committees, who count the number of volumes in a library and divide the total by the number of students. I have never been able to determine what the resulting figure means, in spite of the fact that I have sat on a number of accrediting committees. I have learned, however, that one does not argue with stupidity because one can't win. What are the things then that you are going to tell the actual and potential users about the real value of a library so that they can achieve a proper perspective on its costs? I have been helped immeasurably by librarians when I've come to the library with something I'm reaching for and the librarian has said to me, "This is what you're really looking for." This has happened again and again and again. Not that the librarian understands the subject matter, but the librarian somehow understands the dynamics of information. I don't know how, but an amazing number of them do. They listen to the nonsense I'm saying and hear what I'm really trying to say. They discover what I really want, make sure I get it, and equally important, make sure I know that I got it. It is in developing and publicizing your unique role in the informationtransfer process in an increasingly knowledge- or information-dependent society that the solution to your budget problem lies. Without this, you will be at the mercy of accountants, not because they are petty minded, but because the taxpayers are screaming and the legislature is screaming about the costs being too high. Only if your users understand what they really get from you and understand what its real value is will you get the basic 
constituency support which you need to produce reasonable budgets. I'm not saying I anticipate bad times. I anticipate turbulent times. I also believe that any profession which is dependent on the acceptance by the consumer of its special expertise needs to control its own destiny and direction, and must confront the problem of real value, that is, what can it contribute to society that justifies its support. Otherwise, the bookkeepers will take over. I remember when Mr.
Khrushchev was over here twenty years ago, and there was a lot of talk about who was going to bury whom. Well, it is becoming quite clear that neither the Communists nor the Capitalists are going to bury the other, but that the accountants are going to bury the both of us if we are not effective.

Perhaps this is inevitable, but maybe we can delay it a little bit, and I hope you do your part to help delay it as long as possible.

\section{ON OUR COVER}

Representative of many collegiate buildings of the late nineteenth century is the red brick and stone library of the University of Pennsylvania. Planned by architect Frank Furness, who had consulted Justin Winsor and Melvil Dewey, the new building was begun in 1888 and opened for use on October 1, 1890, having cost about $\$ 200,000$. In the shadow of a 95 -foot tower over the entrance, the main portion of the building was 140 by 80 feet and the book stack 96 by 110 feet. Skylights over reading rooms and offices, and glass floors in the stacks permitted entrance of natural light. Although the library served a student body of fewer than a thousand, the collection already numbered almost 200,000 volumes, and the building had a capacity of half a million. Finally succeeded in 1962 by the Charles Patterson Van Pelt Library, the Furness building now houses the library and studios of the School of Fine Arts.-W. L. Williamson, Professor, University of Wisconsin-Madison

Acknowledgments: Toby Heidtmann, University of Pennsylvania, and Stephen Slovasky, University of Wisconsin-Madison. 